\title{
溶液中におけるクリスタルバイオレットラクトンの 発色および消色の機構
}

\author{
（1982 年 4 月 14 日 受理）
}

薄井耕一・今福繁久*・小野金一・吉川貞雄**

感圧複写紙用発色剤として広く用いられているクリスタルバイオレットラクトン (CVL) の溶液中に 扣ける酸または水による発色执よび減色ないし消色の挙動を UV, VIS, IR 吸収スペクトル执よび ${ }^{1} \mathrm{H}-$ $\mathrm{NMR},{ }^{13} \mathrm{C}-\mathrm{NMR}$ の測定により検討した。并わせて類似の構造をるつクリスタルバイオンット(CV), マラカイトグリーン (MG)，マラカイトグリーンラクトン (MGL) についても比較検討した。

その結果, CVL の発色はラクトンの開環に基づくこと, ラクトンの開いたカルボキシル形ともとの ラクトン形との間には酸濃度 (強度)によって支配される一種の平衡関係が成立し, ある酸強度のとこ ろで，カルボキシル形対ラクトン形の比率が最大值を示し，ここで発色濃度は最大になる。さらに酸濃 度が大きくなるとラクトン環が開いたまま減色することが認められた。一方，水による CVL 発色体 （カルボキシル形）の減色ないし消色は環が閉じラクトン形にもどるためであることが明らかになった。

\section{1 腥 言}

感圧複写紙の現在，全世界で年間 100 万 $\mathrm{t}$ 亿達する生産がなさ れ，日本国内だけでる約 20 万 $\mathrm{t}$ を超えている。

この感圧紙の原料として,もっと.も重要なものに顕色剤と感圧 色素がある。顕色剂には固体酸として種々あるが代表的なるのと しては, クレーとして活性白土類, そしてレジンとして油溶性つ ェノール樹脂, 芳香族カルボン酸誘導体などがあり，これらの顕 色剂はいずれる水に不溶性であるため, 粉破し微粒子状にして原 紙上飞塗布されている。

一方，感圧色素1の代表的なるのにはクリスタルバイオレット ラクトン (以下 CVL と略記する), ベンゼンロイコメチレンブ ルー (BLMB), おょびフルオラン系色素が挙げられる。

この CVL'が固体酸の種類によっては青黒く解明な青にるまた 緑色にもなり，あるいは発色しない場合すある。そして各種の固 体酸上で発色したものを大気中に放置しておくと減色し, 種類に よって減色速度が異なる。空気中で長時間光をあてた場合にも減 色ないし退色して色調が变化する。また，感圧複写紙において複 写された印字がフミンなどの塩基性ガスやエタノールなどの極性 有機溶媒に接したときや水滴がかかったときなどいずれる減色な いし消色して色調を变える。

これらの現象は固体酸の総合的な強弱にも関係があると考党ら れるが，とくに活性白土のよらなクレーと感圧色素との関保にお いてその発色, 減色, 消色; 退色を研究した報告はほとんど見あ たらない。ただ発色の機構に関しては Weitz'2)やKortüm(3) が

水澤化学工業株式会社, 103 東京都中央区日本橋室町

** 東京大学工学部合成化学科, 113 東京都文京区本郷

1) 山本謙二, 色材, 54, 355(1981).

2) E. Weitz, Z. Electrochem., 44, 488(1938); 46, 222 (1940) ; 47, 65(1941).
CVL に類似した構造をもつマラカイトグリーンラクトン(MGL) を固体酸に吸着させ，呈色した粉末の反射スペクトルとマラカイ トグリーン $(\mathrm{MG})$ のメタノール溶液の吸収を比較して同一であっ たことから，呈色の原因はラクトン環の開裂によるメンメリーで 説明している5。また, トリフェニルメタン系染色の色調と酸の 強さとの関係について, 田部ら ${ }^{6)}$ は「酸塩基触媒」の中で図式 1 を用いて説明している。

また, Rune, Cigén?) は水溶液中で $\mathrm{HCl}$ により $\mathrm{pH}$ を変化さ せてクリスタルバイオンット (CV)の可視吸収スペクトルを測定 乙

$$
\begin{aligned}
& {\left[\left(\mathrm{CH}_{3}\right)_{2} \mathrm{NC}_{6} \mathrm{H}_{4}\right]_{2} \mathrm{C}^{+} \mathrm{C}_{6} \mathrm{H}_{4} \mathrm{NH}^{+}\left(\mathrm{CH}_{3}\right)_{2} \longrightarrow \text { 緑色 }} \\
& \left(\mathrm{CH}_{3}\right)_{2} \mathrm{NC}_{6} \mathrm{H}_{4} \mathrm{C}^{+}\left[\left(\mathrm{CH}_{3}\right)_{2} \mathrm{NH}^{+}\left(\mathrm{CH}_{3}\right)_{2}\right]_{2} \longrightarrow \text { 黄色 }
\end{aligned}
$$

であると説明している。さらに CVL の発色および減色に関する 森賀の総説 ${ }^{8}$ がある。

著者らは感王複写紙用に, 活珄白土などの固体酸をよりよい顕 色剂とするため, 活性白土上飞猢色素の発色, 減色および退 色の機構を知ることが一番の早道であると考方研究に着手した が, 肝心の CVL の発色, 減色, 消色の機構が固体酸上に执いて は無諭のこと，溶液中においてさえ直接確かめられていないこと を知り，基本的な溶液中における CVL の発色と減色ないし消色 の挙動を明らかにする必要があると考光, 紫外, 可視部, 赤外吸 収スペクトルおよび ${ }^{1} \mathrm{H}-\mathrm{NMR},{ }^{13} \mathrm{C}-\mathrm{NMR}$ スペクトルの測定に

3) G. Kortüm, Ber., 93, 706(1960).

4) G. Kortüm, Angew. Chem., 70, 651(1958).

5）森賀弘之，小田良平，工化，67，1059(1964).

6）田部浩三, 竹下常一, “酸塩基触媒”, 産業㘡書 (1966) p. 106.

7) Rune, Cigén, Acta Chem. Scand., 12, 1456(1958).

8）森賀弘之，染料之薬品， 4，637(1959). 
<smiles>CN(C)CCc1ccn(C)c1</smiles>

(I)<smiles>CN(C)c1ccc(C(=C2C=CC(C=[N+](C)C)C2)c2ccc([N+](C)(C)C)cc2)cc1</smiles>

(II)<smiles>Cc1ccc(C(c2ccccc2)(c2ccccc2)c2cc[n+](N(C)C)cc2)cc1</smiles>

(III) Malachite Green

Scheme 1<smiles>CN(C)CC(=O)OCC(=O)N(C)C</smiles>

CVL<smiles>CN(C)COC(O)(OCN(C)C)C1CCCO1</smiles>

MGL<smiles>CNOC(COC)(CON(C)C)CON(C)C</smiles>

CV<smiles>CN(C)CC(CO)(CO)CON(C)C</smiles>

MG
Fig. 1 Structural formulae of Crystal Violet lactone (CVL), Crystal Violet (CV), Malachite Green lactone (MGL) and Malachite Green (MG)

より検討した。また比較のため, CVL と似た構造をるつ CV， MGL についても同様の測定を行なった。

\section{2 実験}

\section{1 測定試料}

市肘の CVL, CV および長㖽産業(株)から入手した MGL, $\mathrm{MG}$ を無水エタノール (EtOH) または水で数回再結晶をくり返 し精製したものを試料とした。

\section{2 紫外および可視部スペクトル}

紫外・可視部電子吸収スペクトルの測定には日立 340 型自記分 光光度計を使用した。

\subsubsection{CVL}

(1) CVL-EtOH-HCl 系: $\mathrm{HCl}$ ガスを四収させた $\mathrm{EtOH}$ ( $\mathrm{HCl}$ の含有量は $\mathrm{NaOH}$ の滴定に上り求めた) 飞 CVL を溶解 させ，CVL を一定濃度 $(6.85,13.5 \mathrm{mg} / l)$ として酸量を変化さ せた $\mathrm{EtOH}$ 溶液 $20 \mathrm{~m} l$ を扮のおの調製し, UV, VIS スペクト ルを测定した。ただし CVL は水に溶解せず，また，発色した $\mathrm{CVL}$ が水によって減色するため $\mathrm{HCl}$ ガスおよび $\mathrm{EtOH}$ は脱水 したものを使用した。

酸量は $5.48 \times 10^{-5} \mathrm{HCl} \mathrm{mol} / l$ 溶液から $1.37 \times 10^{-2} \mathrm{~mol} / l$ 溶液 まで変化させた。酸の増加につれて，602nm の吸収は徐々に增

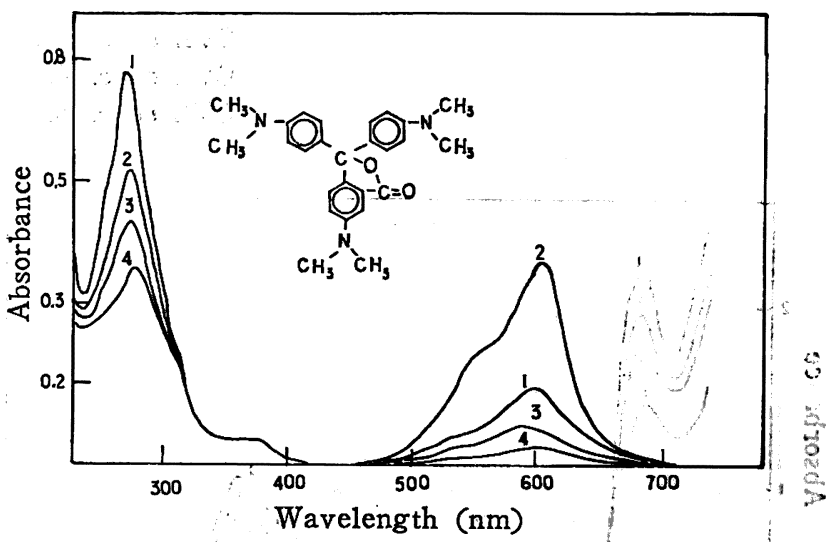

Fig. 2 UV-visible spectra of CVL (CVL-EtOH-HCl system)

$\mathrm{HCl}(\mathrm{mol} / l)$ :

$1 ; 1.07 \times 10^{-4}, 2 ; 4.41 \times 10^{-4}$,

$3 ; 2.67 \times 10^{-8}, \quad 4 ; 5.21 \times 10^{-8}$

大し, 酸賑度 $4.32 \times 10^{-4} \mathrm{HCl} \mathrm{mol} / l$ 溶液で最大を示し,ついで 酸の增加にともなって減少する。

一方, $272 \mathrm{~nm}$ の吸収は酸の增加に之もない減少をつづけ可視 部での吸収が最大となった酸量に近づぐつれて減少は緩やかと なりそその曲線は平らとなって，いったん減少は止まる。その後 $\lambda_{\max } 272 \mathrm{~nm}$ は長波長側にシフトしはじめ (酸濃度 $1.37 \times 10^{-2}$ $\mathrm{HCl} \mathrm{mol} / l$ 溶液では $283 \mathrm{~nm}$ ) 減少割合は大きくなる。また， 362 $\mathrm{nm}$ 付近の吸収については，CVL 濃度を10 倍で行なったが酸に よる変化はみられなかった。図2にスペクトルの代表例定図 3 に 酸量と $\lambda_{\max }$ の関係をまとめた。因 3 に示すように CVL の擞 度を変化させても発色の最大となる酸濃度は $4.32 \times 10^{-4} \mathrm{HCl}$ $\mathrm{mol} / l$ 溶液で同一であった。ちなみに酸濃度を一定として CVL を增加させると直線的に吸収強度は增大し，ある点で一定とな る。

(2) CVL-DMSO-CF ${ }_{3} \mathrm{COOH}$ 系 : CVL Qジメチルスルホキ シド（DMSO）溶液に酸として $\mathrm{CF}_{3} \mathrm{COOH}$ を添加して星色させ た場合のスペクトルを図 4 K，酸量と $\lambda_{\max }$ との関俰を図5にま とめた。CVL の DMSO 溶液 (濃度 $5 \mathrm{~g} / l$ ), $1 \mathrm{ml}$ を採取し,こ れに $\mathrm{CF}_{3} \mathrm{COOH} ， 0.15 \sim 12 \mathrm{~g}$ ををおのおの添加しさらに DMSO を加えて $20 \mathrm{~m} l$ 溶液とし試料を作成した。： 


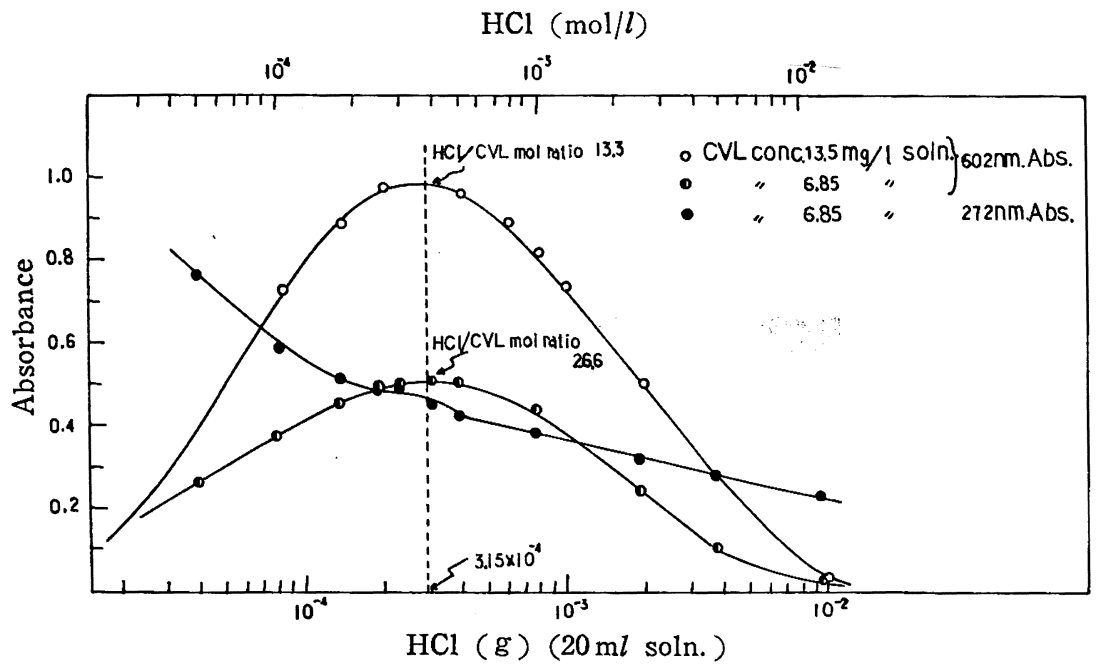

Fig. 3 Absorbances at $602 \mathrm{~nm}$ and $272 \mathrm{~nm}$ in $\mathrm{CVL}-\mathrm{EtOH}-\mathrm{HCl}$ system

CVL conc. $13.5 \mathrm{mg} / l$ soln. ( $(\mathrm{at} 602 \mathrm{~nm}$ )

CVL conc. $6.85 \mathrm{mg} / l$ soln. (O at $602 \mathrm{~nm}$ )

CVL conc. $6.85 \mathrm{mg} / l$ soln. (O at $272 \mathrm{~nm}$ )

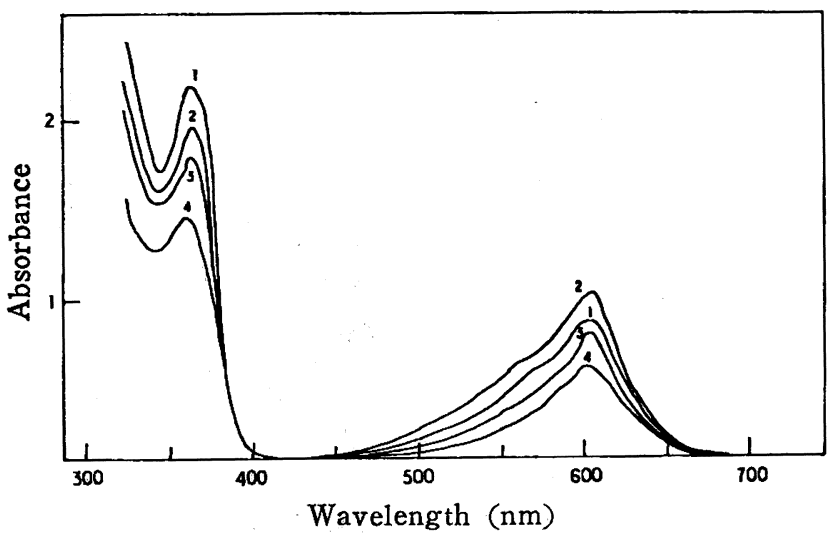

Fig. 4 UV-visible spectra of CVL (CVL-DMSO-CF ${ }_{3} \mathrm{COOH}$ system)

$\mathrm{CF}_{3} \mathrm{COOH}(\mathrm{mol} / l)$ :

$1 ; 0.188,2 ; 0.377,3 ; 1.25,4 ; 4.08$

$\mathrm{CF}_{3} \mathrm{COOH}(\mathrm{mol} / l)$

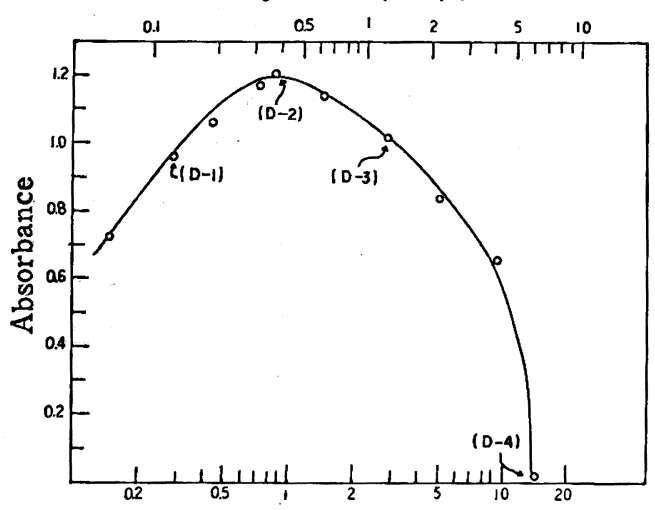

Dosage of $\mathrm{CF}_{3} \mathrm{COOH}(\mathrm{g} / 20 \mathrm{~m} l$ soln. $)$

Fig. 5 Absorbance of CVL at $613 \mathrm{~nm}$ (CVL-DMSO$\mathrm{CF}_{3} \mathrm{COOH}$ system)

$\mathrm{CF}_{3} \mathrm{COOH}(\mathrm{mol} / \mathrm{l})$ :

(D-1) ;0.125, (D-2) ;0.377, (D-3); 1.25

(D-4) ; 6.27
$610 \mathrm{~nm}$ 付近の吸収は酸の増加につれて増大し $\mathrm{CF}_{3} \mathrm{COOH}$ の濃 度 $0.39 \mathrm{~mol} / l$ で最大の吸収を示す。この $0.39 \mathrm{~mol} / l$ 以下の濃度 での $\lambda_{\max }$ は $613 \mathrm{~nm}$ であるが, この濃度以上となると徐々に短 波長側にシフトしはじめ $\mathrm{CF}_{3} \mathrm{COOH}$ 濃度 $5.19 \mathrm{~mol} / l$ では $\lambda_{\max }$ は $603 \mathrm{~nm}$ となる。 $320 \mathrm{~nm}$ より短い波長領域では DMSO の影響 により測定できなかった。また，CVL の濃度を変えた場合，可 視部の $613 \mathrm{~nm}$ の最大の吸収位置は吸光度が大きくなるだけで $\mathrm{CF}_{3} \mathrm{COOH}$ 濃度 $0.39 \mathrm{~mol} / l$ であることに変わりはなかった9)。

(3) $\mathrm{CVL}-\mathrm{C}_{6} \mathrm{H}_{6}-\mathrm{CF}_{3} \mathrm{COOH}$ 系 : CVL のベンゼン溶液に酸と して $\mathrm{CF}_{3} \mathrm{COOH}$ を添加して呈色させた場合の酸量と $\lambda_{\max }$ との 関係を図 6 にまとめた。試料は CVL のベンゼン溶液 (1.010× $\left.10^{-2} \mathrm{~mol} / l\right) 15 \mathrm{ml}$ を採取し, これに $1.0 \mathrm{vol} \%$ の $\mathrm{CF}_{3} \mathrm{COOH}$-ペ ンゼン溶液を所定量加え, さらにベンゼンを加えて総液量がすべ て $20 \mathrm{ml}\left(\mathrm{CVL} 3.1 \mathrm{~g} / l\right.$ ) になるように調製した。 $\mathrm{CF}_{3} \mathrm{COOH} / \mathrm{CVL}$ （モル比）が 2 付近で緑色の油状物質が沈殿しはじめ酸をさらに 添加してゆくと油状物質は青緑色となり, 黄緑色と変化する。そ して最後に淡褐色になって $\mathrm{CF}_{3} \mathrm{COOH}$ に溶解する。暗所に室温 で各試料とも2 日静置後, 上澄液について紫外, 可視部スペクト ル強度から上澄液中の CVL 量を算出した。図6に示したのがそ れである。溶解度の減少し出した点と $610 \mathrm{~nm}$ の吸収の減少しは じめる点が一致することがわかる。この油状物質は発色している

9）“化学便覧”,（基礎編，改訂 2 版，丸善（1975）p.995/999） から $\mathrm{HCl}, \mathrm{CF}_{3} \mathrm{COOH}$ の各溶媒中での酸解離指数 $p K_{a}$ を 推定すると $\mathrm{HCl}$ の水，エタノール中ではそれぞれ - 3.7, 2.1 であり, $\mathrm{CF}_{3} \mathrm{COOH}$ の水, ェタノール, DMSO 中で の $p K_{a}$ は $-0.2,5.4,5.6$ となる.これから CVL-Et・ $\mathrm{OH}-\mathrm{HCl}$ 系と CVL-DMSO- $\mathrm{CF}_{3} \mathrm{COOH}$ 系での $\lambda_{\max }$ の最 大值を与える酸濃度がそれぞれ $4.32 \times 10^{-4} \mathrm{~mol} / l, 3.9 \times$ $10^{-1} \mathrm{~mol} / l$ と $10^{3}$ の濃度比があるが，これは上記 $p K_{a}$ の 差 3.5 に打打よそ対応するとみることができる. さらに水 を溶媒とした場合は, $p K_{a}$ の差 5.8 から $\mathrm{EtOH}$ 中の 4.32

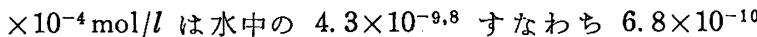
$\mathrm{mol} / l(\mathrm{pH} \mathrm{9.2)}$ 飞相当すると考允られる。事実, 活性白 土を顕色剂とした場合，盗布液の $\mathrm{pH} 9.5$ 付近に調整する ことによって CVL 発色の最大值が得られる. 


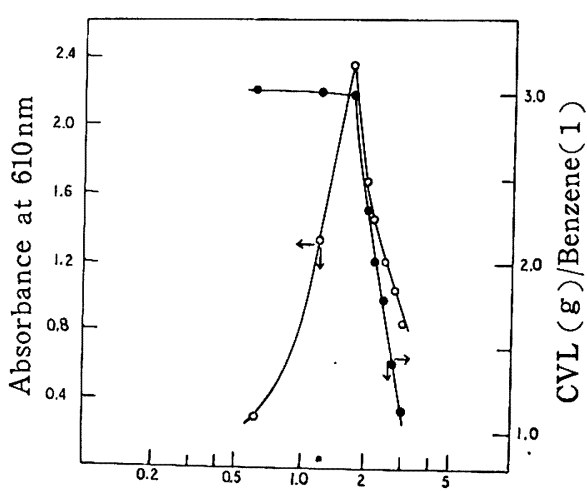

$\mathrm{CF}_{3} \mathrm{COOH} / \mathrm{CVL}$ (mol ratio)

Fig. 6 Absorbances of CVL at $610 \mathrm{~nm}$ and $\mathrm{CVL}(\mathrm{g}) /$ Benzene (1) on various mole ratios of $\mathrm{CF}_{3} \mathrm{COOH} /$ $\mathrm{CVL}\left(\mathrm{CVL}-\mathrm{C}_{6} \mathrm{H}_{6}-\mathrm{CF}_{3} \mathrm{COOH}\right.$ system)

CVL に酸が作用して非極性のベンゼン溶液中で不溶となり沈降 し出したと解することができる。ただしこの油状物質は $\mathrm{EtOH}$, DMSO には溶解して青色となる。

前に述べたように Rune, Cigén ${ }^{7)}$ が水溶液中で $\mathrm{HCl}$ により $\mathrm{pH}$ を変化させて CV の可視吸収スペクトルを測定し， pH の低 下につれて青紫色から緑色, 黄色と変化することを述べている が, 非極性溶媒であるベンゼン中では $\mathrm{CV}$ は無諭のこと, $\left[\left(\mathrm{CH}_{3}\right)_{2} \mathrm{NC}_{6} \mathrm{H}_{4}\right]_{2} \mathrm{C}^{+} \mathrm{C}_{6} \mathrm{H}_{4} \mathrm{NH}^{+}\left(\mathrm{CH}_{3}\right)_{2}$ や $\left(\mathrm{CH}_{3}\right)_{2} \mathrm{NC}_{6} \mathrm{H}_{4} \mathrm{C}^{+}\left[\mathrm{C}_{8} \mathrm{H}_{4}\right.$. $\left.\mathrm{NH}^{+}\left(\mathrm{CH}_{3}\right)_{2}\right]_{2}$ が溶解しないであろうことが考えられ CVL につ いても同様のことが推測できる。

(4) CVL-EtOH-CF 3 COOH 系: $\mathrm{CF}_{3} \mathrm{COOH} / \mathrm{CVL}$ モル比 5 $\times 10^{3}$ で $\lambda_{\max } 602 \mathrm{~nm}$ の吸収は最大を示し, $\mathrm{HCl}$ と $\mathrm{CF}_{3} \mathrm{COOH}$ の解離度の差に基づくものと考えられる。

2.2.2 CV- $\mathrm{H}_{2} \mathrm{O}-\mathrm{HCl}$ 系および CV-EtOH-HCl 系 : CV は溶 媒が水あるいは $\mathrm{EtOH}$ の場合に $\mathrm{HCl}$ との反応が非常に遅いた め, 試料調製後 2 日暗所に室温で静置し测定を行なった。スペク トルを図 7，8に示す。酸の添加につれて $600 \mathrm{~nm}$ 付近の吸収は 小さくなる。同時に長波長測にシフトしはじめて緑色になってく る。またそそにともなって $420 \mathrm{~nm}$ 付近の吸収が大きくなり, また減少する。一方, 紫外部では $300 \mathrm{~nm}$ 付近と $250 \mathrm{~nm}$ 付近に 二つの吸収があり，長波長にシフトしながら（約 $10 \mathrm{~nm}$ ) 減少す る。また，酸を $\mathrm{CF}_{3} \mathrm{COOH}$ に換えた場合， $\mathrm{HCl}$ 系と $\lambda_{\max }$ はま ったく同様であるが， $\mathrm{HCl}$ 系にくらべて同じ吸収強度にするには $\mathrm{CF}_{3} \mathrm{COOH}$ の添加量を多くしなければならなかった。

2.2.3 MGL-EtOH-HCl 系: $20 \mathrm{ml}$ メスフラスコに $3.34 \times$ $10^{-3} \mathrm{~mol} / l$ の $\mathrm{MGL}-\mathrm{EtOH}$ 溶液 $5.0 \mathrm{ml}$ をはかりとり,これに $\mathrm{EtOH}$ を加光約 $10 \mathrm{~m} l$ K希釈し, 所定量の $\mathrm{EtOH}-\mathrm{HCl}$ 溶液を 加え,さらに $\mathrm{EtOH}$ を加えて総量を $20 \mathrm{ml}$ に調整する。図 9 に 酸量と $\lambda_{\max }$ との関係ををとめたものを示す。可視部の 620,410 $\mathrm{nm}$ に吸収があり紫外部では $270 \mathrm{~nm}$ に吸収がある。可視部の二 つの吸収は CVL と同様に酸の増加にともない上昇し，ある点で 減少しだす。紫外部の $270 \mathrm{~nm}$ の吸収は酸の增加につれて CVL と違って単調に娍少するのみである。

2.2.4 $\mathbf{M G}-\mathrm{H}_{2} \mathbf{O}-\mathbf{H C l}$ 系 : スペクトルを図 10 に示す。可視部 に $620 \mathrm{~nm}$ 付近と $420 \mathrm{~nm}$ 付近の 2 籄所に吸収があり, 紫外部に は $320 \mathrm{~nm}$ 付近に綺麗な吸収があるが酸の添加につれていずれも 減少する。

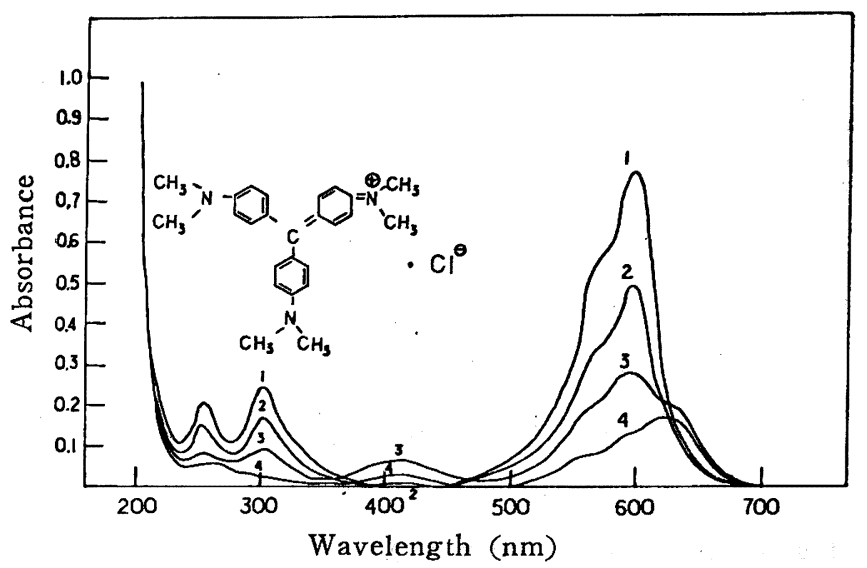

Fig. 7 UV-visible spectra of $\mathrm{CV}\left(\mathrm{CV}-\mathrm{H}_{2} \mathrm{O}-\mathrm{HCl}\right.$ system) $\mathrm{HCl}(\mathrm{mol} / l)$ :

$1 ; 5.00 \times 10^{-4}, \quad 2 ; 2.51 \times 10^{-3}$, $3 ; 1.00 \times 10^{-2}, \quad 4 ; 2.51 \times 10^{-2}$

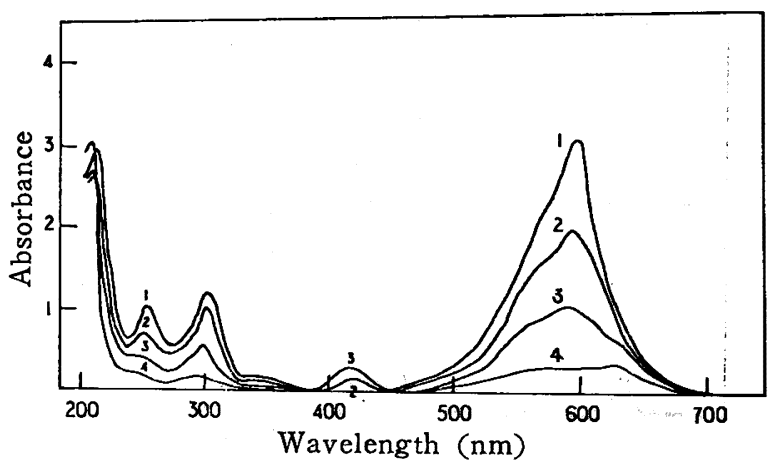

Fig. $8 \mathrm{UV}$-visible spectra of $\mathrm{CV}$ (CV-EtOH-HCl system) $\mathrm{HCl}(\mathrm{mol} / \mathrm{l})$ :

$1 ; 1.37 \times 10^{-2}, \quad 2 ; 5.51 \times 10^{-2}$, $3 ; 2.21 \times 10^{-1}, \quad 4 ; 2.74 \times 10^{-1}$

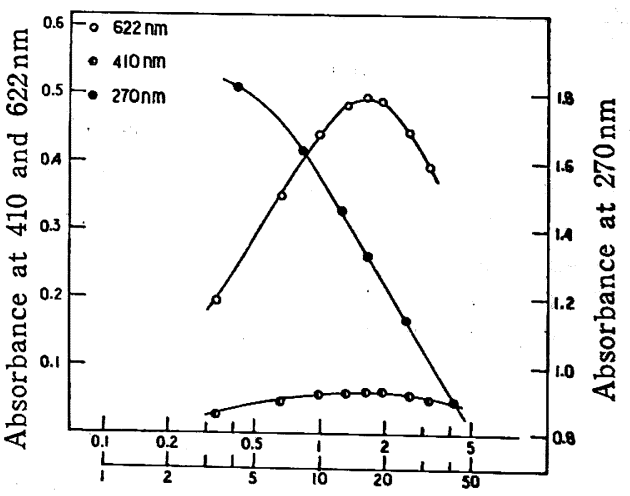

$\mathrm{HCl} / \mathrm{MGL}$ (mole ratio)

Fig. 9 Absorbance of MGL at 410, 622 and $270 \mathrm{~nm}$ (MGL-EtOH-HCl system)

\section{$2.3^{1} \mathrm{H}-\mathrm{NMR}$ 測定}

溶媒としては溶解度の大きいもの，また CVL と相互作用のな いもの，酸としては溶媒と反応しにくいもので無水で取り报いで きるもの，以上のことを検討した結果 CVL-DMSO-CF $3 \mathrm{COOH}$ 系で ${ }^{1} \mathrm{H}-\mathrm{NMR}$ の測定を行なった。装置は日立 R-40 型高分解能 


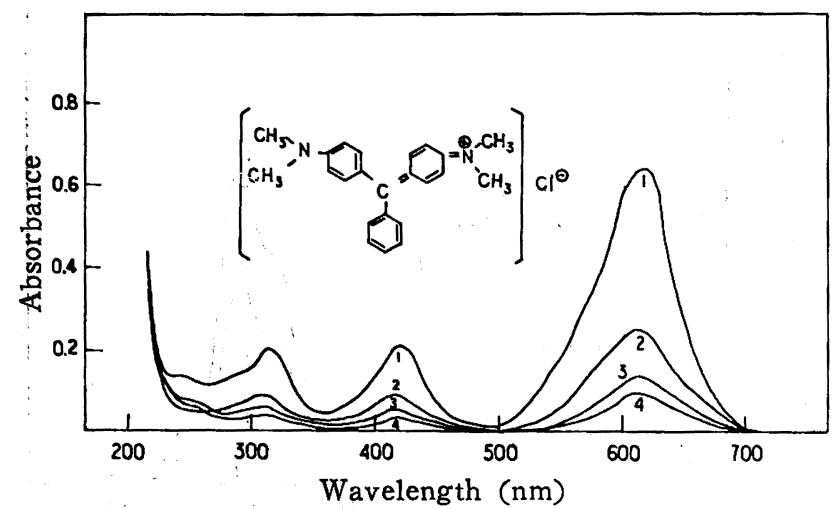

Fig. $10 \mathrm{UV}$-visible spectra of $\mathrm{MG}\left(\mathrm{MG}-\mathrm{H}_{2} \mathrm{O}-\mathrm{HCl}\right.$ system)

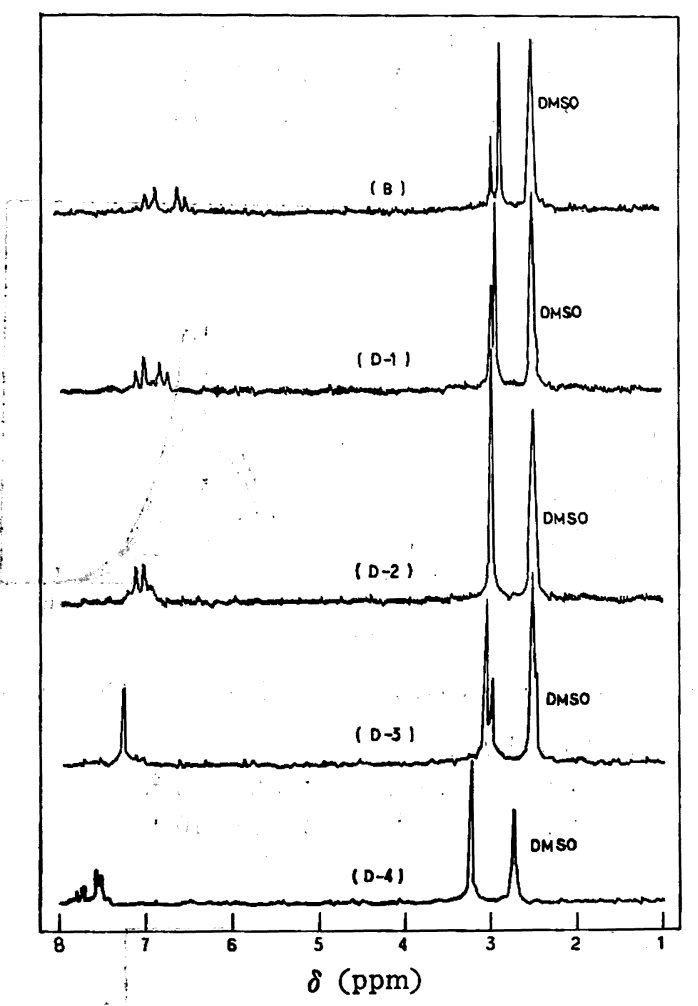

Fig. $11{ }^{1} \mathrm{H}-\mathrm{NMR}$ (CVL-DMSO $\left(d_{6}\right)-\mathrm{CF}_{3} \mathrm{COOH}$ system)
(B) Means blank, i.e. without $\mathrm{CF}_{3} \mathrm{COOH}$ (D-1) : $0.125 \mathrm{CF}_{3} \mathrm{COOH} \mathrm{mol} / l$
(D-2) : $0.377 \mathrm{CF}_{8} \mathrm{COOH} \mathrm{mol} / l$
(D-3) : $1.25 \mathrm{CF}_{3} \mathrm{COOH} \mathrm{mol} / l$
(D-4) : $6.27 \mathrm{CF}_{3} \mathrm{COOH} \mathrm{mol} / l$

核磁気共鳴測定装置である。内部標準として TMSを用いた。試 料番号と可視吸収スペクトルとの関係を図 5 に示し, 测定結果を 図 11 に示す。ただし CVL の濃度は $0.2 \mathrm{~g} / 20 \mathrm{ml}$ とした。

\section{4 水による減色ないし消色}

活性白土を顕色剂に用いたノーカーボン紙の上で発色した CVL は水, $\mathrm{NH}_{3}, \mathrm{HCl}$ などの蒸気または液体（溶液）と混ざるとたち まち減色ないし消色し，または変色する。一方，油溶性フェノー

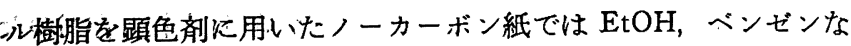
その有機溶媒と混ざるとたちまち消色してしまうという現象があ りこれらがそのままクレーシステムとレシンシステムのそれぞ れの欠点となっている。ここではまず CVL の水による減色ない

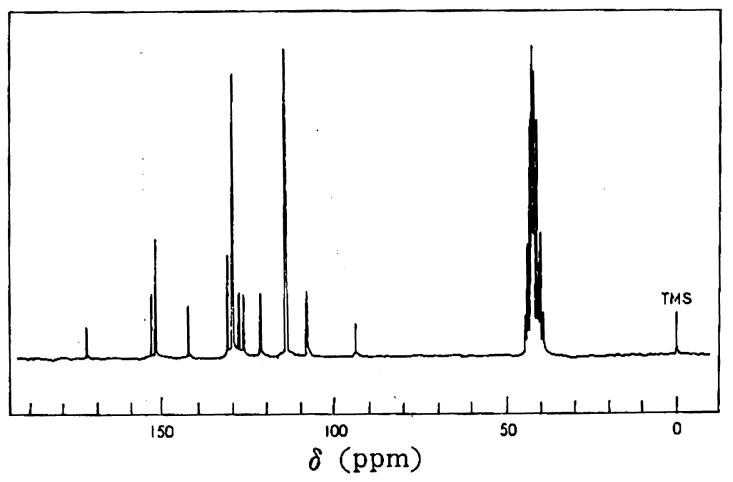

Fig. $12{ }^{13} \mathrm{C}-\mathrm{NMR}\left(\mathrm{CVL}-\mathrm{DMSO}-d_{B}\right)$

し消色について実験を行なった。

(a) : CVL $4.15 \mathrm{~g}$ をベンゼンに溶かし $500 \mathrm{ml}$ とした溶液 と $0.5 \mathrm{~mol} / l$ の $\mathrm{EtOH}-\mathrm{HCl} 20 \mathrm{ml}$ を脱水 $\mathrm{EtOH}$ に溶かし $500 \mathrm{ml}$ とした溶液を混ぜ合わせ，濃青色の溶液 $\left(10^{-2} \mathrm{~mol} \mathrm{CVL-HCl}\right.$ 溶液)を得る。この溶液 $700 \mathrm{~m} l$ を減圧濃縮（留出液 $\mathrm{Cl} \odot$ なし） し, 青色の結晶 (A) を得る。この結晶約 $1 \mathrm{~g}$ を約 $20 \mathrm{ml}$ の脱水 $\mathrm{EtOH}$ に溶かすと濃青色の溶液が得られ，これに多量の水を加え ると白い沈殿が生ずる。この沈股物を吸引沪過し十分に水洗した のち, 風乾し, デシケーター中で乾燥して微青色の粉末を得た。

(b) : 実験 (a) で得られた青色の結晶 A を水に愻濁させると 減色して微青色となる。さらに多量の水を加光吸引沪過しくり返 し水を加えて洗液に $\mathrm{Cl} \ominus$ のなくなるまで水洗をする。これを風 乾しデシケーター中で乾燥して微青色の粉末を得た。それぞれこ の粉末の IR スペクトルの測定を島津 IR-40 測定器により行な った。

(c) $\mathrm{CVL}-\mathrm{EtOH}-\mathrm{H}_{2} \mathrm{O}$ 系における紫外, 可視部吸収スペクト ルの測定 : $135.2 \mathrm{mg} / l$ の CVL-EtOH 溶液 $1 \mathrm{ml}$ に $\mathrm{EtOH} 8 \mathrm{ml}$ を加光，さらに $5.58 \times 10^{-3} \mathrm{~mol} / l$ の $\mathrm{EtOH}-\mathrm{HCl} 1.5 \mathrm{ml}$ 加える。 これに水をおのおの加え， $\mathrm{EtOH}$ で全体を $20 \mathrm{~m} l$ に調整し，暗所 に 2 時間静置後测定した。

\section{$2.5{ }^{13} \mathrm{C}-\mathrm{NMR}$ 測定}

${ }^{1} \mathrm{H}-\mathrm{NMR}$ と同様に CVL-DMSO- $\mathrm{CF}_{3} \mathrm{COOH}$ 系で行なった。 標準物質 TMS は外部標準とした。測定はプロトンデカップリン グ法により，ついでゲーテッドカップリング法で行ないスピン結 合の情報を得ることによって各ピークを帰属させることを試み た。CVLを DMSO- $d_{6}$ に溶解した試料（図 12）を $\mathrm{CF}_{3} \mathrm{COOH}$ によって呈色させ，さらに酸を加えて消色させた試料とでは化学 シフトの違いは見られるがピークの本数は同一であった。

\section{3 結果之考察}

$270 \mathrm{~nm}$ の吸収はラクトン環をもたない CV，MG にはなくラ クトン環をるった CVL，MGL にだけある。このことから 270 $\mathrm{nm}$ の吸収はラクトン環に特徴的な吸収であることがわかる。ラ クトン環に着目してみると， CVL-EtOH-HCl 系（図 3) に拈い ては酸の增加にともなって $270 \mathrm{~nm}$ の吸収が減少しており，ラク トン環が酸により徐々に開裂してゆくことがわかる。それと同時 に可視部の $600 \mathrm{~nm}$ の吸収も徐々に增加してゆき明らかにラクト ン環の開裂が発色を引き起こしていることがわかる。したがって 図式2に示すよらにもとのラクトン型（I）とラクトンの開いた カルボキシル形（II）とが酸の存在のもとに共存しており酸を媒 


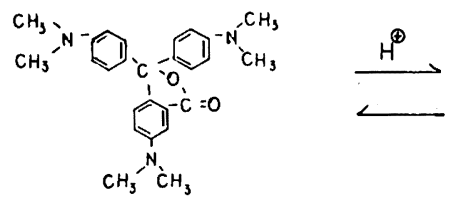

(I)

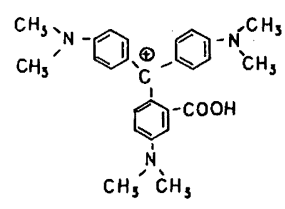

(II)
Scheme 2

介としてこの二つの型が平衡にあり，酸の增加につれてカルボキ シル形の方向に平衡が移動する。

図 3 から，酸の増加にともなって $270 \mathrm{~nm}$ の吸収は可視部の $600 \mathrm{~nm}$ の吸収が最大になるところまで減少をつづけるが減少割 合は緩やかとなり，この境を過ぎると $270 \mathrm{~nm}$ の吸収は徐々に長 波長側に移動しだし減少割合は大きくなることがわかる。同時に 可視部の吸収も緩いカーブで減少し最後には消色する。

一方, この消色した溶液にナトリウムエトキシドを加えて中和 してゆくと（ $\mathrm{NaCl}$ が生成するので暗所に 3 日静置後, 遠沈管に より除去する） $602 \mathrm{~nm}$ の吸収は酸添加時の曲線をたどってもと にもどってゆく。したがって CVL は酸によりラクトン環の開裂 が起こるが，分解は起こらないことがわかる。

このことは ${ }^{1} \mathrm{H}-\mathrm{NMR}$ および ${ }^{13} \mathrm{C}-\mathrm{NMR}$ の挙動によってもわ かる。すなわち ${ }^{13} \mathrm{C}-\mathrm{NMR}$ では酸を加えた場合でもピークの本数 は増加することなくある場所のピークのみが大きくシフトするだ けであること, および ${ }^{1} \mathrm{H}-\mathrm{NMR}$ スペクトルにおいて $-\mathrm{N}\left(\mathrm{CH}_{3}\right)_{2}$ シグナルがつねに 2 本以下しか見られない事実がそれを裹づけて いると考えられる。平衡でなければ他の化学種が生成し，色調の 变化にともなってピークの本数が増加するはずだからである。

つぎに ${ }^{1} \mathrm{H}-\mathrm{NMR}$ スペクトル（図 11）による考察について述 ベる。CVL の DMSO-d 中 $^{1} \mathrm{H}-\mathrm{NMR}$ スペクトルには高磁場 側に $-\mathrm{N}\left(\mathrm{CH}_{3}\right)_{2}$ によ 2 本の一重線, 低磁場側にフェニルプロ トンによる 1 組の多重線が観測される。 $2.8 \mathrm{~nm}$ 付近の 2 本の一 重線の積分比は $2: 1$ になっていることから高磁場の一重線はラ クトン環のついていない側の等価な 2 個の $-\mathrm{N}\left(\mathrm{CH}_{3}\right)_{2}$ に対応し 低磁場側のものはラクトン環のついている側の 1 個の $-\mathrm{N}\left(\mathrm{CH}_{3}\right)_{2}$ と帰属される（図 11-B）。

$\mathrm{CF}_{3} \mathrm{COOH}$ を少量加えた試料（図 11，D-1）でもわずかなシフ トがみられるが，試料 B とほぼ同様のスペクトルである。試料 (D-2) では - $\mathrm{N}\left(\mathrm{CH}_{3}\right)_{2}$ の一重線が重なり 1 本になっている。試 料 (D-3) ではふたたび 2 本の $-\mathrm{N}\left(\mathrm{CH}_{3}\right)_{2}$ シグナルが見られる が，試料（B）とでは逆の位置関係になっている。またフェニル プロトンのシグナルはやや幅をもった一重線になっている。試料 (D-4) では $-\mathrm{N}\left(\mathrm{CH}_{3}\right)_{2}$ が雨度 1 種の一重線となり，またフェニ ルプロトンも多重線として現われてくる。以上の酸の濃度変化に ともなら $\mathrm{NMR}$ スペクトルにおける $-\mathrm{N}\left(\mathrm{CH}_{3}\right)_{2}$ シグナルの変化 と CVL の举動について，さきの電子スペクトルから得た情報と も合わせて以下のような考察を行なった。

CVL の最大発色の試料 (D-2) のところで $-\mathrm{N}\left(\mathrm{CH}_{3}\right)_{2}$ のピー クが 1 種となったのはラクトン環が開裂し，分子全体が共役系と なり 3 個の $-\mathrm{N}\left(\mathrm{CH}_{3}\right)_{2}$ の磁気化学的環境がラクトン環を形成し ている場合にくらべてたがいにかなり近くなったためとみなされ る。試料 (D-3) では酸の增加により一部の $-\mathrm{N}\left(\mathrm{CH}_{3}\right)_{2}$ にプロト ン付加が起こり, 共役系の一部切断がなされ, その結果 2 種の
$-\mathrm{N}\left(\mathrm{CH}_{3}\right)_{2}$ が生じ 2 本の $-\mathrm{N}\left(\mathrm{CH}_{3}\right)_{2}$ シグナルが現われたるのと 考えられる。

この推測は $\mathrm{CVL}-\mathrm{C}_{6} \mathrm{H}_{6}-\mathrm{CF}_{8} \mathrm{COOH}$ 系（図 6) において酸の濃 度が CVL の最大発色を過ぎたところでは緑色がかっており, 共 役の程度は青色のときに比較して少々小さいが無色の CVL の場 合より大きいと思われることも対応づけられる。酸が大過剩にあ る試料 (D-4) では完全に消色している。これは過剰の酸により 共役系が CVL 程度になったものと考えられ, 共役の度合が減少 するための要因としては - $\mathrm{N}\left(\mathrm{CH}_{3}\right)_{2}$ への $\mathrm{H}^{+}$の付加が挙げられ る。(D-4) においてたた一種の $-\mathrm{N}\left(\mathrm{CH}_{3}\right)_{2}$ シグナルが観測され るのは $\mathrm{H}^{+}$が付加した 3-個の $-\mathrm{N}\left(\mathrm{CH}_{3}\right)_{2}$ の磁気的環境が非常に 似てきたためと考えられる。

つぎに，水による減色ないし消色作用に関して述べる。(a)の 実験においては，溶媒中で発色している状態の CVIに多量の水 を加えた場合であり，（b ）の実験柱溶媒のない状態すなわち活性 白土表面で発色している CVL が水によって消色することを想定 した場合である。（a ）（b ）とも得られた微青色の粉末はIR 炕 よって測定したところ，CVL そのものであった。すなわち溶媒 中で発色している系においても，CVLを溶かす溶媒をほ之んと 含まないような系においても水の介入によ放て CVL 発色体が閉 環して，もとの CVLにもどるということがわかる。

多量の水を加えないでわずかずつ水が加わってゆく途中の現象 はどうなっているのであろうか，これは溶媒中で発色している系 を用いて（c）の実験によって行ならた。結果を図 13 に示す。水 が增加するにつれて酸により発色していた CVLがたんだと消 色してゆくことは $600 \mathrm{~nm}$ の吸収の減少からかかる。まだ, ラク トン環を示す $270 \mathrm{~nm}$ の吸収が増加してゆくことからラクトンが 閉環してゆくことがわかる。

$\mathrm{H}_{2} \mathrm{O} / \mathrm{CVL}$ モル比が $3 \times 10^{5}$ を境にラグン環が開き出してい るが，これは我に拈ける $\mathrm{HCl}$ の解離度と $\mathrm{EtOH}$ 中に和けるとれ の差によるためと考えられる。すなわち $\mathrm{EtOH}$ 中では解離度が 水にくらべて非常に小さい。したがって水の量が増加するにつれ て $\mathrm{HCl}$ の酸としての働きが大きくなりふたたびラクトン環を開 かせるようになったと思われる。600 nm の吸収が徐々に増加 (発色が強い方向に向う) しつつあるのはこれを裏づけている。

すなわち最初にふれた Kortüm は「MGL は種々の Salts の 表面と混ざると格子の陽イオンの分極化作用により一部ラクトン 環の開裂による両性イオンの生成を起こし, このような化学吸着 種 (青色) と物理吸着種（無色）の平衡に達する」と説明してい

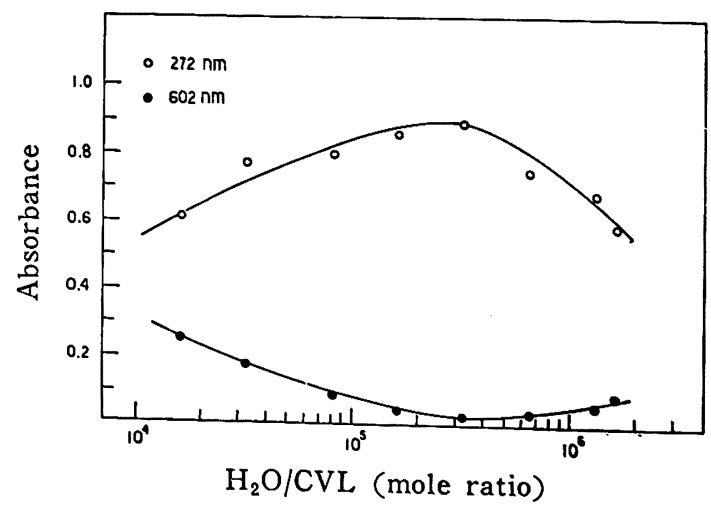

Fig. 13 Absorbances of CVL at $272 \mathrm{~nm}$ and $602 \mathrm{~nm}$ (CVL-EtOH- $\mathrm{H}_{2} \mathrm{O}$ system) 


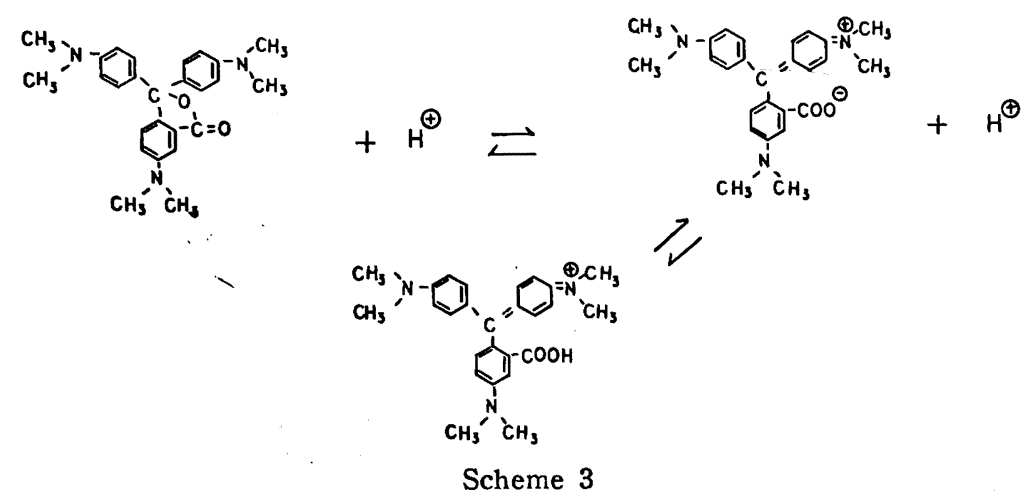

るが, 著者らの研究からも CVL のラクトン環の開閉はきわめて 可逆的であることがわかっており, 図式 3 に示すように EtOH$\mathrm{HCl}$ 溶液中において平衡にあると考えられる。すなわち CVL は不安定な両性イオンを中間体として陽イオン(カルボキシル形) と平衡関係にある。したがってこのように水を加えてやると水は 塩基として働き陽イオンのカルボキシル基から $\mathrm{H} \oplus$ が引き抜か れ不安定な両性イオンを通って平衡は CVL に移ってゆく,さら に多量の水を加えると系は CVL を溶解する能力を失いCVL の 沈殿をともないながら不可逆的に安定な CVL を生成してゆくと 考えられる。

\section{4 ま と め}

固体酸上では固体酸の種類により CVL の色調が違らが,これ は溶液中において酸濃度 (強度)によって CVL の色調が違うの とよく似ており，固体酸の酸強度による要素が大さいためと解さ れる。事実固体酸の $p K_{a}$ の大小によって色調が変わることはよ く知られている。そして CVL の発色, 減色, 消色の程度は酸の 量ではなく酸の濃度もしくは酸の強度に依存している。また, 溶 液中における CVL はラクトン形 (無色) とラクトン環の開いた カルボキシル形 (発色) の二つの形が酸の存在のもとに平衡にあ
り，酸の増加につれてカルボキシル形の方向に平衡が移動する。 また，溶液中における CVLにアルカリを加劣ても発色しない が，酸によって消色した CVLにアルカリを加えてゆくと発色し てゆき最後に消色してもとの CVLにもどる事実は以上述べてき た実験事実と合わせて，CVL の酸による消色はラクトン環の開 いたままの状態であることが認められる。

水による减色および消色は，以上述べてきたように固体酸上で

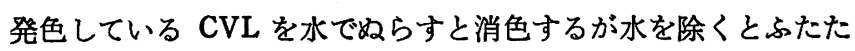
び発色するという事実は, 溶液中に拈ける CVL に水を加えてい ったときの CVL の挙動と同じであるといえる。すなわち CVL が極端な水に対する不溶性のため, 溶液内での平衡が無色のラク トン環を生成する方向にずれることによると考えられる。

以上のよらな基本的な実験でも，溶液中における CVL の発 色, 減色, 消色が固体酸上でのそれのモデル実験としての情報を 与えているものとみなされる。

最後に本研究を進めるにあたり, 研究を許可いたたいた前水澤 化学工業株式会社社長故菅原勇次郎氏, ならびに御指導を賜わり ました東京大学工学部合成化学科矢野重信講師, ならびに吉川研 究室の方々に深甚の謝意を表する次第です。 


\title{
Mechanism of Color-Developing and Fading in the Solution of Crystal Violet Lactone
}

\author{
Koichi Usur, Shigehisa Imafuku*, Kin'ichi Ono \\ and Sadao YoshiKawa** \\ Mizusawa Industrial Chemicals, Ltd.; Nihombashi-muromachi, \\ Chuo-ku, Tokyo 103 Japan \\ ** Department of Synthetic Chemistry, Faculty of Engineering, \\ The University of Tokyo; Hongo, Bunkyo-ku Tokyo 113 Japan
}

The color-developing and discoloring effect of acid, such as $\mathrm{HCl}, \mathrm{CF}_{8} \mathrm{COOH}$ and $\mathrm{CH}_{3} \mathrm{CO}$. $\mathrm{OH}$, or water on Crystal Violet lactone (CVL), which is used widely as a coloring material for pressure-sensitive copying system, has been investigated by means of UV and visible spectrometry, ${ }^{1} \mathrm{H}-\mathrm{NMR}$ and ${ }^{13} \mathrm{C}-\mathrm{NMR}$ in the solution of ethanol, benzene, DMSO or water.

The behavior of Crystal Violet (CV), Malachite Green (MG) and Malachite Green lactone (MGL), which have similar structures to CVL, were also investigated for comparison. It is recognized that the color-developing of $\mathrm{CVL}$ is based on the opening of the lactone ring, and an equilibrium which depends on acid concentration (or acid strength) exists between carboxylform. It is indicated that the ratio of the carboxyl-form to the lactone-form reaches its maximum at an appropriate acid strength, where the intensity of the developed color is the highest. The increase of the acid concentration reduces the intensity of the developed color still retaining the carboxyl-form. It seems that the phenomenon is caused by the protonation to dimethylamino groups of CVL. The fading or discoloring of CVL (carboxyl-form) with water is caused by the formation of lactone ring. 